\title{
EDITH PECHEY-PHIPSON, M.D.: UNTOLD STORY
}

by

\section{EDYTHE LUTZKER}

ON 7 October, 1845, in the village of Langham near Colchester, Essex, England, a daughter whom they called Mary Edith was born to Baptist Minister William Pechey and his wife Sarah. As Miss Edith Pechey, and later as Dr. Pechey-Phipson, this daughter did so much, in so many ways, to help move the world forward, that her story deserves to be told.

Born in the eighth year of the reign of Queen Victoria, and surviving the Queen by less than a decade, the sixty-three years of her remarkable life thus are part of the story of the Victorian era, that period of widespread social ferment, and of great humanitarian reforms-reforms bitterly opposed, and won only at tremendous cost to those who engaged in the struggles for them.

There was little education for girls in England then. Rarely indeed did they attend any of the existing schools. Very young daughters of the poor worked as domestic servants or mill hands; middle-class girls were taught at home by under-educated governesses. Edith Pechey was more fortunate. Her father had been a brilliant John Ward Scholar at the University of Edinburgh, from which he received an M.A. degree; and besides his service to his church, he was the author of religious works, and active in the administration of the school maintained by the nonconformists in his parish. Her mother also was competent in Greek and other studies and both parents possessed-along with their questing nonconformist minds-a deep and serious love of learning. Edith Pechey grew up in that love, was an earnest student, and later, for a few years, a teacher. And in October 1869 she was one of the five courageous women (including Sophia Jex-Blake, who initiated the daring enterprise) who fought to be admitted to the University of Edinburgh as medical students.

After many interviews with professors on the various governing bodies of this austere institution, they were permitted to sit for the qualifying examination in arts, a requirement for university enrolment. They all did well, and were admitted with the stipulation that they would be taught in special classes, separate from the male students. In effect, this meant the payment of four times the regular tuition fees. As fees were then being paid not to the university but directly to the professors, they had to be sufficient to make it worth the professor's time to lecture to a group of five.

For the next years, each term found the women's names on the honours lists. However, theirs was not an easy road to learning, for many of the male students went to considerable lengths to harrass and annoy them, publicly and privately, sometimes even obscenely, with the covert approval of a few professors. At one point, a riot was staged at the gates of Surgeons' Hall as the women were about to enter for an anatomy examination. The result of that riot was a trial on the charge of libel against Sophia Jex-Blake; but the verdict of one farthing damages awarded to the plaintiff was some indication of the sympathies of the community. 


\section{Edythe Lutzker}

A further affront to the male student ego: Edith Pechey as first-year student qualified for a chemistry prize of $£ 200$ - of which she was in great need-and more important to her, the right of access to the chemistry laboratory, hitherto denied the women students. She had been using a makeshift affair which she had set up in the quarters she shared with Miss Jex-Blake, and the possibility of access to the university's laboratory was most exhilarating-until she learned that the prize had been denied her, as a woman, and given to a male second-year student, next on the list. The denial of this prize incensed not only the five women students, but also the more enlightened sections of the community. Their indignation led a number of Edinburgh citizens, many of them of some prominence, to form a Committee to Secure a Complete Medical Education for Women in Edinburgh.

Their outstanding academic performance during their years at Edinburgh did not, however, win for these women the right to complete their medical education and receive medical degrees. The university finally ousted them in 1874 , on the grounds that it had 'exceeded its authority' in admitting them in the first place, and thus had no further responsibility toward them. Before their expulsion, they had sued the university and won a favourable decision from the High Court of Scotland. The university appealed, and the verdict was reversed by a single vote. Moreover, the women were compelled to pay all the legal costs, including the university's appeal, to the extent of some $£ 2,000$. The Committee to Secure a Complete Medical Education for Women in Edinburgh came to their rescue, asking the public to lend them financial aid and moral support, both of which were generously forthcoming.

These women, who were not to be discouraged, deterred or diverted from their purpose, decided to continue their medical studies on the continent. Both Edith Pechey and Sophia Jex-Blake received an M.D. at the University of Berne in January 1877. In May of that year, Edith Pechey was admitted to the qualifying examinations in Dublin, and at the monthly examination meeting the Censors certified that she should be allowed the licence to practise medicine, with the seal of the Royal College of Physicians of Ireland attached to such certification. At last, Dr. Pechey was free to turn full attention to the alleviation of human suffering through the 'useful and honourable profession' of medicine.

In October 1877, Dr. Pechey delivered the inaugural address at the London School of Medicine for Women, the school founded on the initiative of the five women during the course of their heroic struggle to open the field of medicine to women. Incisive, wise, and enlivened by her own characteristic gentle humour, this address was an early indication of one phase of her professional life-a life in which, from many platforms in many places, Edith Pechey brought enlightenment to many people.

After several years of medical practice and lecturing in Leeds, Dr. Pechey was in Vienna for additional practice in surgery when she was offered the post of Senior Medical Officer of the proposed Cama Hospital in Bombay, India. A wealthy Parsee philanthropist, P. H. Cama, had offered to endow a hospital there for women and children, to be staffed entirely by women. Since religious laws did not permit Indian women to be treated by male physicians, and since, except for a few missionaries with some medical training, there were no women physicians in India, the importance of this undertaking can hardly be overestimated. An American business man, George 


\section{Edith Pechey-Phipson, M.D.}

A. Kittredge, who lived and worked in Bombay, had initiated the Medical Women for Indian Fund. In this he was supported by many, including prominent Parsees and Hindus. The fund intended to bring women doctors from England, to build the hospital to be staffed by women, and to persuade the medical school of the University of Bombay, and the Grant Medical College, to admit Indian women for medical education. Eventually the Fund succeeded in all these objectives. In pursuit of the first aim, namely, to bring women doctors to India from England, Mr. Kittredge met with Edith Pechey in Paris in 1883. She promised that she would carefully consider accepting the post of Senior Medical Officer at the not-yet-built hospital, at a guaranteed salary of Rs. $\mathbf{5 0 0}$ per month, plus living quarters and first-class passage out and home. Returning a little later to Leeds, she turned her practice and her rooms over to a friend and colleague and embarked upon a most significant journey. She arrived in Bombay on 12 December 1883. Perhaps she had never really had any doubts as to her decision. As she wrote later from India, ' . . . there is a great need for someone to initiate a movement here.' Thus Edith Pechey, among her many distinctions, was the first Senior Medical Officer in the first hospital in the world to be staffed entirely by women.

Pending the completion of the hospital, a temporary dispensary was opened to which the poorer women came for treatment. At once Dr. Pechey realized that to be effective in changing the lives and outlook of these women, she must learn to communicate with them in their own language, and along with her other responsibilities and duties, she began an intensive study of Hindustani. Her self-respecting and dignified professional attitude was shown by one of her first administrative acts. With the support of the trustees of the Fund, she won for herself and her staff the same salary as was paid to men doctors in comparable positions, in the belief that lesser compensation to women physicians would undermine their professional status, and encourage the lingering suspicion that in this field women were not as well qualified as men.

Dr. Pechey entered quickly into Indian intellectual and professional life. In the year after her arrival she became a member of the Royal Asiatic Society of Bombay, whose members were scholars; later she served as its Vice-President. In England she had been active among the gallant few who struggled against the enmity or the indifference of the many to shatter Victorian taboos, particularly to break through the barriers set up against women in medicine. She came to India at a time when many socio-religious laws and age-old traditions were under scrutiny and challenge by an enlightened and liberal segment of the Indian people. Child marriage; the proscribed re-marriage of widows, even child widows; education for girls; the vast and overwhelming problems of public health-these were some of the areas in which reforms were called for; reforms that were bitterly opposed by orthodox Hindus on religious grounds. Purdah and zenana systems which isolated females from every male member of the household except their husbands, were stubbornly defended by orthodox Mohammedans as well as by Hindus.

As the logic of her whole life would dictate, Dr. Pechey was no more neutral in these struggles in India than she had been in England. A cause celèbre in which she became involved was the case of Rukhmabai. Married at eleven years of age to an 


\section{Edythe Lutzker}

orthodox Hindu, Rukhmabai refused to go to live with her husband; whereupon he brought legal action for restitution of his conjugal rights. The affair became a national scandal. Some years later she decided that she wanted to study medicine. Dr. Pechey encouraged the young girl to remain firm of purpose and offered to make it possible for her to go to the London School of Medicine for Women. Rukhmabai did go to England, returned to India in 1894 with a medical degree, and was in time, appointed Chief Medical Officer of two hospitals, one in Rajkot and the other in Surat. These appointments were largely due to the influence of Dr. Pechey, now Dr. Edith PecheyPhipson. Not long after her arrival in India, she had met Herbert Phipson, a wine merchant, a reformer, and a naturalist. He had helped to found the Natural History Society of Bombay and served as its Honorary Secretary for more than twenty years. He was also much interested in, and for several years an officer of the Medical Women for India Fund. He and Edith Pechey were married in March 1889.

In 1890 Dr. Pechey-Phipson addressed the Hindus of Bombay on the evils of child marriage, dealing with that highly controversial subject from the medical and psychological aspects, a talk favourably received by her male audience. One man ordered it translated into twenty of the most widely-used languages of India and had many thousands of copies printed at his own expense to ensure wide distribution.

Edith Pechey-Phipson was the first woman honoured by appointment to the Senate of the University of Bombay. She held the post of Senior Medical Officer at the Cama Hospital from its completion in 1886 until 1894, when she retired to continue in private practice. She was the moving and widely opposed force behind the drive for a nurses' training school to be connected with the Cama Hospital, and did not give up until it was established. A tireless advocate of expansion of educational opportunities for girls, she was also a staunch supporter of the few schools in existence. Her profound interest in education for women brought her an invitation to preside at the prize distribution ceremonies of the Alexandra Native Girls' English School, founded in 1863, and her address to these young ladies was an impassioned plea for them to continue their education through college, university and the professional academies, and to help to secure education for all the women of India.

In 1891, Edith and her husband founded the Pechey-Phipson Sanatorium on their own summer estate at Nasik Road, about 120 miles north of Bombay, where the climate is drier, and the countryside is beautiful. Here they built several cottage units, and families without means of escaping the insufferable heat of the Bombay summer were invited to come for a month's stay; convalescent women and children especially were encouraged to take advantage of a health-renewing sojourn at rent-free, and only nominal cost. Bombay newspapers published notices of such accommodations, directing interested readers to apply to Phipson and Co., through whom all arrangements would be made. And so they are to this day, with the number of cottages now twenty-three, with one additional building used as a library and one devoted to badminton.

When in 1894 Dr. Pechey-Phipson retired from her hospital post to private practice, her health was already severely undermined and she was suffering from diabetes. Nevertheless, when in 1896 bubonic plague broke out in Bombay, followed by a cholera epidemic and famine which raged throughout India for the next four years, 


\section{Edith Pechey-Phipson, M.D.}

she immediately offered her services, and throughout all these terrible years, gave the full measure of her life's devotion to the art of healing. After the first inevitable newspaper denials of the reality of the epidemic, Bombay began to deal with the crisis. The city was divided into wards. In the wards where no hospital existed, they were improvised, and all medical personnel was mobilized, with house-to-house visitation and disinfection teams. Dr. Pechey-Phipson was assigned to the Mohammedan quarter of the 2nd Nagpada District. Early in 1897-which one newspaper described as a year 'of sorrow, not for Bombay alone but for the whole continent . . . the blackest in the whole history of India ... - she was assigned to the medical staff of the Cutchi Menon Plague Hospital, but this private hospital remained open for only a few months, and she resumed her work of house visitation and treatment of the stricken.

When Dr. Pechey-Phipson returned with her husband to England in 1905, though she was already ill, she was drawn into the campaign for female suffrage. After her twenty-two rugged years in India, and the earlier intense struggle to achieve professional status for herself and for all women who sought to serve humanity, she could not withdraw from all her activities. With her husband she visited Canada, which had recently gone through its own struggle to achieve medical education for women. They went to Australia and to New Zealand also. Edith wrote of days 'crowded with engagements which brought us into contact with work in women's suffrage, medicine and education ...'In August 1906 she represented the Leeds Women's Suffrage Association at the International Conference of the Women's Suffrage Alliance in Copenhagen, and reported on this Conference at a meeting in Leeds, in October. This report was wise and witty, and delivered in high spirit. In February, 1907 , there was a demonstration sponsored by the Central Society for Women's Suffrage in London, called a 'Mud March.' Reported as walking in the front line of that march were four women: Mrs. Fawcett, LL.D., the Lady Frances Balfour, Lady Strachey-and Mrs. Pechey-Phipson, M.D.

Some time after that march, it was necessary for her to submit to surgery. It is noteworthy that her surgeon was Dr. May Thorne, daughter of her friend and colleague throughout the struggle for a medical degree from the University of Edinburgh. The operation was successful, but in her frail condition perhaps full recovery was too much to hope for. She died of cancer and in a diabetic coma, on 14 April, 1908, at Folkestone, in the land of her birth, where so little is known of her story.

\section{NOTE}

Mrs. Edythe Lutzker, M.A., Columbia University, U.S.A., is at present working on a biography of Dr. Edith Pechey-Phipson. In the interest of this work, she would like information about the present whereabouts of personal papers, correspondence, and four volumes of India diaries by Elizabeth Adelaide Manning (1828-1905), who was General Secretary and Honorary Secretary and Treasurer of the London Branch of the National Indian Association from 1870 to 1905. She made two trips to India, one in 1889 and the other in 1899. To the best of Mrs. Lutzker's present knowledge, these diaries have not been published. She would like to know also about diaries, correspondence, autobiographies, personal papers, etc., of Dr. Edith Pechey-Phipson (1845-1908); Dr. Sophia Jex-Blake (1840-1912); and Dr. Margaret Todd (1859-1918). There is a possibility that Edith PecheyPhipson went to Yokohama, Japan. The flyleaf of a book from her personal library, now in the library of the Pechey-Phipson Sanatorium, in her own handwriting, mentions Yokohama without giving a date. If any reader of this article has information confirming this, Mrs. Lutzker would be pleased to hear of it. Please address replies to the author, 201 West 89th Street, New York 24, N.Y., U.S.A. 